\title{
Prevalence and antibiotic resistance of Salmonella isolated from poultry and its environment in the Mekong Delta, Vietnam
}

\author{
Thuan K. Nguyen ${ }^{1}$ (D), Lam T. Nguyen ${ }^{1}$ (D), Trang T. H. Chau ${ }^{1}$, Tam T. Nguyen ${ }^{1}$, Bich N. Tran $^{1}$, Takahide Taniguchi $^{2}$, \\ Hideki Hayashidani² ${ }^{\mathbb{D}}$ and Khai T. L. Ly ${ }^{1}$ id
}

1. Department of Veterinary, College of Agriculture, Can Tho University, Campus II, 3/2 Street, Ninh Kieu District, Can Tho City, Vietnam; 2. Cooperative Department of Veterinary Medicine, Division of Animal Life Science, Institute of Agriculture, Tokyo University of Agriculture and Technology, 3-5-8 Saiwai-cho, Fuchu-shi, Tokyo 183-8509, Japan. Corresponding author: Thuan K. Nguyen, e-mail: nkthuan@ctu.edu.vn

Co-authors: LTN: ntlam@ctu.edu.vn,TTHC: cthtrang@ctu.edu.vn,TTN: nttamty@ctu.edu.vn, BNT: tnbich@ctu.edu.vn, TT: taniguti@cc.tuat.ac.jp, HH: eisei@cc.tuat.ac.jp, KTLL: Itlkhai@ctu.edu.vn

Received: 03-08-2021, Accepted: 22-11-2021, Published online: 30-12-2021

doi: www.doi.org/10.14202/vetworld.2021.3216-3223 How to cite this article: Nguyen TK, Nguyen LT, Chau TTH, Nguyen TT, Tran BN, Taniguchi T, Hayashidani H, Ly KTL (2021) Prevalence and antibiotic resistance of Salmonella isolated from poultry and its environment in the Mekong Delta, Vietnam, Veterinary World, 14(12): 3216-3223.

\begin{abstract}
Background and Aim: Salmonella is one of the leading causes of zoonotic and foodborne infectious outbreaks in humans and poultry and its associated environment is a potential reservoir of Salmonella. In recent years, the antibiotic resistance of bacteria, including Salmonella, has been increasing. This study aimed to investigate the prevalence and antibiotic resistance of Salmonella isolated from poultry, its environment, and the pest animals found at poultry farms and households of the Mekong Delta, Vietnam.

Materials and Methods: A total of 3,055 samples were collected from the broiler farms and households of the Mekong Delta from 2017 to 2020. Salmonella was isolated using conventional methods (culturing on selective agar - BPLS and biochemical test) and the isolates were examined for antibiotic resistance against 14 antibiotics using the disk diffusion method.

Results: Salmonella was isolated from 181 samples (5.92\%), which included chicken feces (7.67\%), pest animals (5.98\%), and environmental samples (4.33\%). The environmental samples comprised bedding (5.88\%), feed (5.48\%), and drinking water $(0.70 \%)$. The prevalence of Salmonella was the highest in rats $(15.63 \%)$ and geckos $(12.25 \%)$ followed by ants (2.83\%) and cockroaches (2.44\%); however, Salmonella was not isolated from any fly species. Most of the isolates exhibited resistance to 1-9 antibiotics. The isolates were relatively resistant to chloramphenicol (62.98\%), tetracycline (55.80\%), ampicillin (54.14\%), and sulfamethoxazole/trimethoprim (53.04\%). Sixty-two multiple resistance patterns were found in the isolates, with ampicillin-cefuroxime-chloramphenicol-tetracycline- sulfamethoxazole/trimethoprim being the most frequent $(7.18 \%)$.
\end{abstract}

Conclusion: The chickens, husbandry environment, and pest animals at poultry farms and households were found to be important Salmonella sources in the Mekong Delta. Salmonella isolates from these sources also exhibited a wide-ranging resistance to antibiotics as well as several resistance patterns. Hence, biosecurity should be addressed in poultry farms and households to prevent cross-contamination and reduce the spread of Salmonella infections.

Keywords: antibiotic resistance, chickens, environment, farms, Salmonella, wild animals.

\section{Introduction}

Salmonella enterica subsp. enterica is an important infection causing pathogen for warmblooded animals and commensal organisms for coolblooded animals, such as reptiles and amphibians [1]. Human salmonellosis is a zoonotic infection as it is caused due to contact with farm or pest animals, either directly through feces or indirectly through food and the environment [2]. Interactions among the chickens, husbandry environment (such as feed, drinking water, and workers), and pest animals (such

Copyright: Nguyen, et al. Open Access. This article is distributed under the terms of the Creative Commons Attribution 4.0 International License (http://creativecommons.org/licenses/ by/4.0/), which permits unrestricted use, distribution, and reproduction in any medium, provided you give appropriate credit to the original author(s) and the source, provide a link to the Creative Commons license, and indicate if changes were made. The Creative Commons Public Domain Dedication waiver (http:// creativecommons.org/publicdomain/zero/1.0/) applies to the data made available in this article, unless otherwise stated. as rodents, reptiles, and insects) increase the spread of Salmonella.

Poultry is known to harbor significant numbers of Salmonella serovars without showing clinical signs of the infection [3]. Salmonella prevalence is relatively high in chickens and, consequently, farm environments [4-6]. On the other hand, the infected flocks without previous vaccination could be result in almost $100 \%$ morbidity and about $20 \%$ mortality [7]. Horizontal and vertical transmission by multiple routes complicates the epidemiology of Salmonella infections. Moreover, 46.4\% of human Salmonella infections are linked to animal sources, mostly from poultry [8]. Most foodborne outbreaks in humans due to consumption of contaminated poultry products are also caused due to Salmonella [9]. These outbreaks highlight the risk of Salmonella infections that originate from poultry and adversely affect human health. However, to the best of our knowledge, the prevalence 
of Salmonella in poultry farms and households of the Mekong Delta is largely unknown.

Due to the overuse of antimicrobial agents, antibiotic-resistant Salmonella isolates are found worldwide $[10,11]$. The misuse of antimicrobials in animal feeds or for the treatment of both humans and animals leads to the selection of resistant bacterial strains. Animals with antibiotic-resistant zoonotic Salmonella strains transmit the infection to humans through the food chain [12]. Salmonella strains isolated from poultry farms also show multiple resistance patterns for numerous antibiotics [13-17] and display genetic relationships with the Salmonella strains detected in humans [14,15]. Thus, the antibiotic-resistant Salmonella strains in poultry and farm environments should be carefully monitored.

Some information on the prevalence of Salmonella in poultry farms outside of Vietnam is available, but, to the best of our knowledge, a comprehensive study of the sources of Salmonella in farms and households of the Mekong Delta has not yet been conducted. Poultry and its environment could be critical sources of Salmonella infections for animals and humans in this area.

This study aimed to investigate the prevalence and antibiotic resistance of Salmonella isolated from poultry, its environment, and the pest animals found at poultry farms and households of the Mekong Delta, Vietnam.

\section{Materials and Methods}

\section{Ethical approval}

The feces were collected from healthy broilers. Pest animals were caught and dissected in the welfare conditions. This study was carried out under the permission of the laboratory biosafety guideline from Can Tho University, Vietnam.

\section{Study period, location, and sample collection}

From October 2017 to December 2020, 3055 samples were collected from the broiler farms and households of the Mekong Delta, Vietnam. The samples included chicken feces $(\mathrm{n}=417)$; environmental samples, including bedding $(\mathrm{n}=170)$, feed $(\mathrm{n}=219)$, and drinking water $(\mathrm{n}=142)$; and pest animals, including rats $(n=32)$, geckos $(n=808)$, flies $(n=450)$, ants $(n=530)$, and cockroaches $(n=287)$.

Chicken feces were collected by swabbing the cloacal into the transporter medium, Carry-Blair (Merck ${ }^{\circledR}$ Germany). The environmental samples, including the feed $(250 \mathrm{~g})$, drinking water $(1000 \mathrm{~mL})$, and bedding $(250 \mathrm{~g})$, were collected directly from the chicken barns, placed in sterilized bags, and stored at $2-8^{\circ} \mathrm{C}$. The pest animals (geckos, ants, cockroaches, and rats) were captured in traps and placed separately in sterilized plastic boxes with ventilation holes. All samples were transported to the laboratory on the day of sampling itself.

In the laboratory, the geckos were euthanized by freezing at $-20^{\circ} \mathrm{C}$ for $5 \mathrm{~min}[18,19]$ and the rats were euthanized with chloroform (Merck). The animals were dissected at room temperature $\left(28-30^{\circ} \mathrm{C}\right)$ and the feces were individually and aseptically collected from the rectum. Ungureanu method for dissecting insects [20] was modified to dissect the collected ants, cockroaches, and flies by freezing at $-20^{\circ} \mathrm{C}$ for $5 \mathrm{~min}$. Salmonella isolates were cultured from all the animal bodies. The procedures for animal dissection and feces collection followed the laboratory biosafety guidelines of Can Tho University.

\section{Salmonella isolation and identification}

The samples (chicken feces, environmental samples, and pest animal contents) were diluted to 9 times their volume with buffered peptone water (BPW) (Merck ${ }^{\circledR}$, Germany) for incubation at $37^{\circ} \mathrm{C}$ for $24 \mathrm{~h}$. One milliliter of the BPW broth was transferred into $9 \mathrm{~mL}$ of the enrichment broth (Rappaport Vassiliadis soya [RVS] broth) $\left(\right.$ Merck $\left.^{\circledR}\right)$ for additional incubation at $37^{\circ} \mathrm{C}$ for $24 \mathrm{~h}$. One loop of the RVS broth was streaked on Brilliant-green Phenol-red Lactose Sucrose agar $\left(\right.$ Merck $\left.^{\circledR}\right)$ to isolate Salmonella. The suspicious Salmonella colonies were picked after incubation at $37^{\circ} \mathrm{C}$ for $24 \mathrm{~h}$. Subsequent biochemical identification was performed as previously described by Tran et al. [21].

\section{Antimicrobial susceptibility testing}

A total of 181 Salmonella isolates were examined for antibiotic susceptibility with 14 antibiotic agents (Nam Khoa Ltd., Vietnam), including ampicillin $(10 \mu \mathrm{g})$, amikacin $(30 \mu \mathrm{g})$, amoxicillin/clavulanic acid $(20 / 10 \mu \mathrm{g})$, ceftazidime $(30 \mu \mathrm{g})$, chloramphenicol $(30 \mu \mathrm{g})$, colistin $(10 \mu \mathrm{g})$, cefuroxime $(30 \mu \mathrm{g})$, doxycycline $(30 \mu \mathrm{g})$, gentamicin $(10 \mu \mathrm{g})$, levofloxacin $(5 \mu \mathrm{g})$, ofloxacin $(5 \mu \mathrm{g})$, tetracycline $(30 \mu \mathrm{g})$, streptomycin $(10 \mu \mathrm{g})$, and sulfamethoxazole/trimethoprim (Bactrim) (23.75/1.25 $\mu \mathrm{g})$. These antibiotics were used to treat salmonellosis in chickens in the poultry farms of the Mekong Delta. Escherichia coli ATCC 25922 and E. coli ATCC 35218 were used as controls. The disk diffusion method from the standards of the Clinical Laboratory Standards Institute procedure M02-M07 [22] was conducted to assess the antibiotic resistance of Salmonella isolates.

\section{Statistical analysis}

Data were expressed as percentages. The differences in the prevalence of Salmonella in the samples collected from the husbandry environment and pest animals were tested using Chi-square test, as were each kind of sample from the farms and households. The statistical significance level was set at $\mathrm{p}<0.05$. Data collection and manipulation were conducted using Microsoft Excel (Microsoft, USA). Statistical analysis was performed using the Statistical Package for the Social Sciences statistical package, version 7.1 (IBM, USA).

\section{Results}

Salmonella was detected in 181 of the 3055 samples (5.92\%) (Table-1). Salmonella was present in the 
chicken feces, environmental samples, and pest animals $(7.67 \%, 5.98 \%$, and $4.33 \%$, respectively). No statistical difference was observed in the prevalence of Salmonella among these samples ( $>>0.05)$. There were no significant differences in the comparative prevalence of Salmonella in each kind of sample from the farms and households ( $p>0.05)$.

Salmonella was significantly higher in bedding $(5.88 \%)$ and feed $(5.48 \%)$ than in drinking water $(0.70 \%)(p<0.05)$. No significant difference in the comparative prevalence of Salmonella in the bedding and feed samples from the farms and households was observed ( $p>0.05)$. However, Salmonella was only detected from one drinking water sample from a household (Table-2).

The prevalence of Salmonella in rats (15.63\%) and geckos $(12.25 \%)$ was significantly higher than in ants $(2.83 \%)$ and cockroaches $(2.44 \%)(\mathrm{p}<0.05)$. However, no significant difference in the comparative prevalence of Salmonella in these samples from the farms and households was seen $(\mathrm{p}>0.05)$. Salmonella was not isolated from any fly or cockroach samples collected from the farms or households (Table-3).

Salmonella isolates were moderately resistant to four antibiotics, chloramphenicol $(62.98 \%)$, tetracycline $(55.80 \%)$, ampicillin $(54.14 \%)$, and sulfamethoxazole/trimethoprim (53.04\%). However, the isolates were sensitive $(60.22-99.45 \%)$ to nine other antibiotics (Table-4).

A total of 121/181 Salmonella isolates (66.85\%) exhibited resistance to 2-9 antibiotics (Table-5) and 62 multiple resistance patterns were observed. The popular resistance pattern included ampicillin-cefuroxime-chloramphenicol-tetracycline-sulfamethoxazole/ trimethoprim (7.18\%), ampicillin-cefuroxime-chloramphenicol-levofloxacin-tetracycline-sulfamethoxazole/trimethoprim (4.97\%), ampicillin-chloramphenicol-tetracycline-sulfamethoxazole/trimethoprim (4.97\%), and chloramphenicol-tetracycline-sulfamethoxazole/trimethoprim (3.31\%).

\section{Discussion}

Salmonella is an important zoonotic pathogen; its presence in animal food products is a continuous threat of infection to humans [23]. Salmonella can be transmitted to chickens through horizontal and vertical routes. The largely asymptomatic infected animals can spread infections across the poultry supply chain. The prevalence of Salmonella isolated from chicken feces $(7.67 \%)$ in this study was similar to the previous reports; Alali et al. [24] reported that Salmonella was isolated from broiler feces in organic

Table-1: Prevalence of Salmonella in the poultry farms and households in the Mekong Delta, Vietnam.

\begin{tabular}{|c|c|c|c|c|c|c|}
\hline \multirow[t]{2}{*}{ Samples } & \multicolumn{2}{|c|}{ Households } & \multicolumn{2}{|c|}{ Farms } & \multicolumn{2}{|c|}{ Total } \\
\hline & $\begin{array}{c}\text { No. of } \\
\text { examined } \\
\text { samples }\end{array}$ & $\begin{array}{c}\text { No. of } \\
\text { positive } \\
\text { samples (\%) }\end{array}$ & $\begin{array}{c}\text { No. of } \\
\text { examined } \\
\text { samples }\end{array}$ & $\begin{array}{c}\text { No. of } \\
\text { positive } \\
\text { samples (\%) }\end{array}$ & $\begin{array}{c}\text { No. of } \\
\text { examined } \\
\text { samples }\end{array}$ & $\begin{array}{c}\text { No. of } \\
\text { positive } \\
\text { samples }(\%)\end{array}$ \\
\hline Feces & 247 & $18(7.29)$ & 170 & $14(8.24)$ & 417 & $32(7.67)$ \\
\hline Environment & 336 & $15(4.46)$ & 195 & $8(4.10)$ & 531 & $23(4.33)$ \\
\hline Wild animals & 1,007 & $60(5.96)$ & 1,100 & $66(6.00)$ & 2,107 & $126(5.98)$ \\
\hline Total & 1,590 & $93(5.85)$ & 1,465 & $88(6.01)$ & 3,055 & $181(5.92)$ \\
\hline
\end{tabular}

Table-2: Prevalence of Salmonella in the environmental samples in the poultry farms and households.

\begin{tabular}{|c|c|c|c|c|c|c|}
\hline \multirow[t]{2}{*}{ Samples } & \multicolumn{2}{|c|}{ Households } & \multicolumn{2}{|c|}{ Farms } & \multicolumn{2}{|c|}{ Total } \\
\hline & $\begin{array}{c}\text { No. of } \\
\text { examined } \\
\text { samples }\end{array}$ & $\begin{array}{l}\text { No. of positive } \\
\text { samples }(\%)\end{array}$ & $\begin{array}{c}\text { No. of } \\
\text { examined } \\
\text { samples }\end{array}$ & $\begin{array}{c}\text { No. of } \\
\text { positive } \\
\text { samples (\%) }\end{array}$ & $\begin{array}{c}\text { No. of } \\
\text { examined } \\
\text { samples }\end{array}$ & $\begin{array}{l}\text { No. of positive } \\
\text { samples }(\%)\end{array}$ \\
\hline Bedding & 102 & $6(5.88)$ & 68 & $4(5.88)$ & 170 & $10(5.88)^{a}$ \\
\hline Feed & 137 & $8(5.84)$ & 82 & $4(4.88)$ & 219 & $12(5.48)^{a}$ \\
\hline Drinking water & 97 & $1(1.03)$ & 45 & $0(0.00)$ & 142 & $1(0.70)^{b}$ \\
\hline
\end{tabular}

The different exponent letters in one column indicate the significant statistical difference $(p<0.05)$

Table-3: Prevalence of Salmonella in wild animals in the poultry farms and households.

\begin{tabular}{|c|c|c|c|c|c|c|}
\hline \multirow[t]{2}{*}{ Species } & \multicolumn{2}{|c|}{ Households } & \multicolumn{2}{|c|}{ Farms } & \multicolumn{2}{|c|}{ Total } \\
\hline & $\begin{array}{c}\text { No. of } \\
\text { examined } \\
\text { samples }\end{array}$ & $\begin{array}{l}\text { No. of positive } \\
\text { samples }(\%)\end{array}$ & $\begin{array}{l}\text { No. of } \\
\text { examined } \\
\text { samples }\end{array}$ & $\begin{array}{l}\text { No. of positive } \\
\text { samples }(\%)\end{array}$ & $\begin{array}{c}\text { No. of } \\
\text { examined } \\
\text { samples }\end{array}$ & $\begin{array}{l}\text { No. of positive } \\
\text { samples }(\%)\end{array}$ \\
\hline Geckos & 398 & $50(12.56)$ & 410 & 49 (11.95) & 808 & $99(12.25)^{a}$ \\
\hline Ants & 260 & $5(1.92)$ & 270 & $10(3.70)$ & 530 & $15(2.83)^{\mathrm{b}}$ \\
\hline Flies & 180 & $0(0.00)$ & 270 & $0(0.00)$ & 450 & $0(0.00)$ \\
\hline Cockroaches & 137 & $0(0.00)$ & 150 & $7(4.67)$ & 287 & $7(2.44)^{b}$ \\
\hline Rats & 32 & $5(15.63)$ & 0 & $0(0.00)$ & 32 & $5(15.63)^{a}$ \\
\hline
\end{tabular}

The different exponent letters in one column indicate the significant statistical difference $(\mathrm{p}<0.05)$ 
Table-4: The antibiotic resistance of Salmonella isolated in the poultry farms and households $(n=181)$.

\begin{tabular}{|c|c|c|c|c|}
\hline \multirow[t]{2}{*}{ Antibiotic } & \multicolumn{2}{|c|}{ Sensitivity } & \multicolumn{2}{|c|}{ Resistance } \\
\hline & No. of isolates & Percentages & No. of isolates & Percentages \\
\hline $\mathrm{Am}$ & 83 & 45.86 & 98 & 54.14 \\
\hline Ac & 175 & 96.69 & 6 & 3.31 \\
\hline$A k$ & 180 & 99.45 & 1 & 0.55 \\
\hline $\mathrm{Cz}$ & 179 & 98.90 & 2 & 1.10 \\
\hline $\mathrm{Cu}$ & 109 & 60.22 & 72 & 39.78 \\
\hline $\mathrm{Cl}$ & 67 & 37.02 & 114 & 62.98 \\
\hline Co & 159 & 87.85 & 22 & 12.15 \\
\hline$D x$ & 159 & 87.85 & 22 & 12.15 \\
\hline $\mathrm{Ge}$ & 169 & 93.37 & 12 & 6.63 \\
\hline LV & 164 & 90.61 & 17 & 9.39 \\
\hline Of & 176 & 97.24 & 5 & 2.76 \\
\hline $\mathrm{Sm}$ & 131 & 72.38 & 50 & 27.62 \\
\hline $\mathrm{Te}$ & 80 & 44.20 & 101 & 55.80 \\
\hline Bt & 85 & 46.96 & 96 & 53.04 \\
\hline
\end{tabular}

Am=Ampicillin, Ac=Amoxicillin/clavulanic acid, Ak=Amikacin, $\mathrm{Cz}=$ Ceftazidime, $\mathrm{Cu}=$ Cefuroxime, $\mathrm{Cl}=\mathrm{Ch}$ loramphenicol, $\mathrm{Co}=$ Colistin, $\mathrm{Dx}=$ Doxycycline, $\mathrm{Ge}=$ Gentamycin, $\mathrm{L} v=$ Levofloxacin, Of=Ofloxacin, Sm=Streptomycin, Te=Tetracycline, $\mathrm{Bt}=$ Sulfamethoxazole/trimethoprim

(5.6\%) and conventional (38.8\%) farms in North Carolina, USA. Further, Salmonella was detected in chickens in broiler farms in Japan (7.9\%) [5], India (2.5\%) [25], and Nepal (10.6\%) [26]. The prevalence of Salmonella isolated from backyard chickens was $3.5 \%$ in Paraguay [27] and $12.7 \%$ from free-range chickens in China [15]. Salmonella was also detected in chickens in pluck shops (6.1\%) in Trinidad [28]. Thus, chickens can be considered a potential source of Salmonella infections in the Mekong Delta.

The prevalence of non-typhoidal Salmonella can be found in environmental reservoirs, infections from which are challenging to control [29]. No significant differences in the prevalence of Salmonella among chicken, environmental, and pest animal samples from farms and households were seen in the present study. Salmonella might be present regardless of the livestock scale because of continuous cross-contamination of the pathogen among the media present in the farm environments. Ahmed et al. [30] determined that chickens and poultry environments were important reservoirs of Salmonella in Nigeria. In chicken farms, Salmonella can be transmitted through feces, vehicles, workers, clothing, footwear, equipment, water, food, garbage, animals, and other factors [3,31]. A large number of chickens in flocks makes farm biosecurity and good farm management practices difficult [32].

Our field observations indicated that sanitation was not guaranteed in either farms or households. The feeding and drinking water trough use was manual and the chickens could drop their feces into either food or water that could lead to contamination with Salmonella. However, we did not detect Salmonella in the drinking water samples taken from the farms. Clean water was a concern at the farms and, hence, was replaced more frequently during the day than in the households. Alali et al. [24] suggested that the contamination of feed in the feed pans was likely due to fecal droppings. Feeds, especially in the deep litter management systems, can become a potential source of Salmonella contamination [33,34]. Further, the prevalence of Salmonella was reported as 0.26$38.8 \%$ in the feed and $0.6-27.5 \%$ in the drinking water $[4,24,26,35]$. Thus, Salmonella can be transmitted back and forth among the chickens through contaminated feed and water. Further investigation could help clarify the cross-contamination routes of Salmonella in the environment and flocks at both the farms and households.

The sources of Salmonella in poultry might also include pest animals [36]. These animals (rodents, insects, reptiles, etc.) enter the poultry farms and households through holes in the walls or floors. The prevalence of such pest animals poses a threat for the spread of Salmonella contamination. Mian et al. [37] indicated that flies (Musca domestica) were present in large numbers at poultry farms and harbored Salmonella. However, Salmonella was not isolated from the fly samples in this study. The natural habitats of flies in the Mekong Delta, such as food sources, the frequency of the contact of the flies with Salmonella sources (feces, wastes, dead animals, etc.), and hygiene practices in the area might have played a limiting role in the transmission of the pathogen at the farms through flies. The prevalence of Salmonella in flies is also related to the seasonal increases in fly activity on the farms and the concurrent cross-contamination within the farm environment [38].

Rodents and lizards might also be important sources of Salmonella infections in poultry [35,36]. We isolated Salmonella from lizard $(2.5 \%)$ and rodent $(2.8 \%)$ sampled from the poultry farms [35]. Nwachukwu et al. [39] reported that $25.7 \%$ of common house geckos (Hemidactylus frenatus) living in Nigeria were Salmonella positive. Nguyen et al. $[40,41]$ found that the feces of pest geckos harbored Salmonella in large numbers and were a potential source of Salmonella infections in the Mekong 
Table-5: The multiple antibiotic resistance patterns of Salmonella isolated in the poultry farms and households ( $\mathrm{n}=181$ ).

\begin{tabular}{|c|c|c|c|}
\hline No. of resistant antibiotics & Resistance patterns & No. of patterns & No. of isolates $(\%)$ \\
\hline \multirow[t]{8}{*}{2} & $A m-A c$ & 8 & $2(1.10)$ \\
\hline & $\mathrm{Am}-\mathrm{Cl}$ & & $1(0.55)$ \\
\hline & $\mathrm{Am}-\mathrm{Co}$ & & $1(0.55)$ \\
\hline & $\mathrm{Cl}-\mathrm{Bt}$ & & $2(1.10)$ \\
\hline & $\mathrm{Cl}-\mathrm{Co}$ & & $1(0.55)$ \\
\hline & $\mathrm{Cl}-\mathrm{Te}$ & & $1(0.55)$ \\
\hline & Sm-Bt & & $1(0.55)$ \\
\hline & Sm-Te & & $2(1.10)$ \\
\hline \multirow[t]{7}{*}{3} & $\mathrm{Am}-\mathrm{Ac}-\mathrm{Co}$ & 7 & $1(0.55)$ \\
\hline & $\mathrm{Am}-\mathrm{Cl}-\mathrm{Bt}$ & & $1(0.55)$ \\
\hline & $\mathrm{Am}-\mathrm{Cl}-\mathrm{Co}$ & & $1(0.55)$ \\
\hline & $\mathrm{Cl}-\mathrm{Co}-\mathrm{Bt}$ & & $1(0.55)$ \\
\hline & $\mathrm{Cl}-\mathrm{Sm}-\mathrm{Bt}$ & & $1(0.55)$ \\
\hline & $\mathrm{Cl}-\mathrm{Sm}-\mathrm{Te}$ & & $1(0.55)$ \\
\hline & $\mathrm{Cl}-\mathrm{Te}-\mathrm{Bt}$ & & $6(3.31)$ \\
\hline \multirow[t]{8}{*}{4} & $\mathrm{Am}-\mathrm{Cl}-\mathrm{Sm}-\mathrm{Bt}$ & 8 & $3(1.66)$ \\
\hline & $\mathrm{Am}-\mathrm{Cl}-\mathrm{Sm}-\mathrm{Te}$ & & $3(1.66)$ \\
\hline & $\mathrm{Am}-\mathrm{Cl}-\mathrm{Te}-\mathrm{Bt}$ & & $9(4.97)$ \\
\hline & $\mathrm{Am}-\mathrm{Cu}-\mathrm{Cl}-\mathrm{Bt}$ & & $2(1.10)$ \\
\hline & $\mathrm{Am}-\mathrm{Cu}-\mathrm{Cl}-\mathrm{Te}$ & & $1(0.55)$ \\
\hline & $\mathrm{Cl}-\mathrm{Lv}-\mathrm{Te}-\mathrm{Bt}$ & & $1(0.55)$ \\
\hline & $\mathrm{Cl}-\mathrm{Sm}-\mathrm{Te}-\mathrm{Bt}$ & & $2(1.10)$ \\
\hline & $\mathrm{Cu}-\mathrm{Cl}-\mathrm{Te}-\mathrm{Bt}$ & & $2(1.10)$ \\
\hline \multirow[t]{11}{*}{5} & $\mathrm{Am}-\mathrm{Ac}-\mathrm{Cl}-\mathrm{Sm}-\mathrm{Bt}$ & 11 & $1(0.55)$ \\
\hline & $\mathrm{Am}-\mathrm{Cl}-\mathrm{Co}-\mathrm{Te}-\mathrm{Bt}$ & & $1(0.55)$ \\
\hline & $\mathrm{Am}-\mathrm{Cl}-\mathrm{Ge}-\mathrm{Sm}-\mathrm{Bt}$ & & $1(0.55)$ \\
\hline & $\mathrm{Am}-\mathrm{Cl}-\mathrm{Ge}-\mathrm{Te}-\mathrm{Bt}$ & & $1(0.55)$ \\
\hline & Am-Cl-Lv-Te-Bt & & $1(0.55)$ \\
\hline & $\mathrm{Am}-\mathrm{Cl}-\mathrm{Sm}-\mathrm{Te}-\mathrm{Bt}$ & & $1(0.55)$ \\
\hline & $\mathrm{Am}-\mathrm{Cu}-\mathrm{Cl}-\mathrm{Sm}-\mathrm{Te}$ & & $3(1.66)$ \\
\hline & $\mathrm{Am}-\mathrm{Cu}-\mathrm{Cl}-\mathrm{Te}-\mathrm{Bt}$ & & $13(7.18)$ \\
\hline & $\mathrm{Am}-\mathrm{Cu}-\mathrm{Sm}-\mathrm{Te}-\mathrm{Bt}$ & & $1(0.55)$ \\
\hline & $\mathrm{Cl}-\mathrm{Dx}-\mathrm{Sm}-\mathrm{Te}-\mathrm{Bt}$ & & $1(0.55)$ \\
\hline & $\mathrm{Cu}-\mathrm{Cl}-\mathrm{Sm}-\mathrm{Te}-\mathrm{Bt}$ & & $1(0.55)$ \\
\hline \multirow[t]{10}{*}{6} & $\mathrm{Am}-\mathrm{Ac}-\mathrm{Cz}-\mathrm{Cu}-\mathrm{Co}-\mathrm{Bt}$ & 10 & $1(0.55)$ \\
\hline & $\mathrm{Am}-\mathrm{Cl}-\mathrm{Dx}-\mathrm{Ge}-\mathrm{Sm}-\mathrm{Te}$ & & $1(0.55)$ \\
\hline & $\mathrm{Am}-\mathrm{Cu}-\mathrm{Cl}-\mathrm{Co}-\mathrm{Dx}-\mathrm{Sm}$ & & $1(0.55)$ \\
\hline & $\mathrm{Am}-\mathrm{Cu}-\mathrm{Cl}-\mathrm{Co}-\mathrm{Dx}-\mathrm{Te}$ & & $4(2.21)$ \\
\hline & $\mathrm{Am}-\mathrm{Cu}-\mathrm{Cl}-\mathrm{Co}-\mathrm{Te}-\mathrm{Bt}$ & & $2(1.10)$ \\
\hline & $\mathrm{Am}-\mathrm{Cu}-\mathrm{Cl}-\mathrm{Dx}-\mathrm{Te}-\mathrm{Bt}$ & & $2(1.10)$ \\
\hline & $\mathrm{Am}-\mathrm{Cu}-\mathrm{Cl}-\mathrm{Ge}-\mathrm{Te}-\mathrm{Bt}$ & & $1(0.55)$ \\
\hline & $\mathrm{Am}-\mathrm{Cu}-\mathrm{Cl}-\mathrm{Lv}-\mathrm{Te}-\mathrm{Bt}$ & & $9(4.97)$ \\
\hline & $\mathrm{Am}-\mathrm{Cu}-\mathrm{Cl}-\mathrm{O}-\mathrm{Te}-\mathrm{Bt}$ & & $1(0.55)$ \\
\hline & $\mathrm{Am}-\mathrm{Cu}-\mathrm{Cl}-\mathrm{Sm}-\mathrm{Te}-\mathrm{Bt}$ & & $6(3.31)$ \\
\hline \multirow[t]{12}{*}{7} & $\mathrm{Ac}-\mathrm{Cu}-\mathrm{Cl}-\mathrm{Ge}-\mathrm{Sm}-\mathrm{Te}-\mathrm{Bt}$ & 12 & $1(0.55)$ \\
\hline & Am-Ak-Cu-Cl-Dx-Sm-Te & & $1(0.55)$ \\
\hline & $\mathrm{Am}-\mathrm{Cu}-\mathrm{Cl}-\mathrm{Co}-\mathrm{Dx}-\mathrm{Sm}-\mathrm{Te}$ & & $1(0.55)$ \\
\hline & Am-Cu-Cl-Co-Dx-Te-Bt & & $1(0.55)$ \\
\hline & $\mathrm{Am}-\mathrm{Cu}-\mathrm{Cl}-\mathrm{Co}-\mathrm{Lv}-\mathrm{Te}-\mathrm{Bt}$ & & $1(0.55)$ \\
\hline & $\mathrm{Am}-\mathrm{Cu}-\mathrm{Cl}-\mathrm{Dx}-\mathrm{Ge}-\mathrm{Sm}-\mathrm{Te}$ & & $1(0.55)$ \\
\hline & $\mathrm{Am}-\mathrm{Cu}-\mathrm{Cl}-\mathrm{Dx}-\mathrm{Sm}-\mathrm{Te}-\mathrm{Bt}$ & & $3(1.66)$ \\
\hline & Am-Cu-Cl-Ge-Lv-Te-Bt & & $1(0.55)$ \\
\hline & $\mathrm{Am}-\mathrm{Cu}-\mathrm{Cl}-\mathrm{Ge}-\mathrm{Sm}-\mathrm{Te}-\mathrm{Bt}$ & & $1(0.55)$ \\
\hline & $\mathrm{Am}-\mathrm{Cu}-\mathrm{Cl}-\mathrm{Gr}-\mathrm{Sm}-\mathrm{Te}-\mathrm{Bt}$ & & $1(0.55)$ \\
\hline & $\mathrm{Am}-\mathrm{Cu}-\mathrm{Cl}-\mathrm{Lv}-\mathrm{Sm}-\mathrm{Te}-\mathrm{Bt}$ & & $1(0.55)$ \\
\hline & $\mathrm{Am}-\mathrm{Cu}-\mathrm{Cl}-\mathrm{O}-\mathrm{Sm}-\mathrm{Te}-\mathrm{Bt}$ & & $1(0.55)$ \\
\hline \multirow[t]{5}{*}{8} & $\mathrm{Am}-\mathrm{Cu}-\mathrm{Cl}-\mathrm{Co}-\mathrm{Dx}-\mathrm{Sm}-\mathrm{Te}-\mathrm{Bt}$ & 5 & $3(1.66)$ \\
\hline & $\mathrm{Am}-\mathrm{Cu}-\mathrm{Cl}-\mathrm{Dx}-\mathrm{Ge}-\mathrm{Sm}-\mathrm{Te}-\mathrm{Bt}$ & & $1(0.55)$ \\
\hline & $\mathrm{Am}-\mathrm{Cu}-\mathrm{Cl}-\mathrm{Dx}-\mathrm{Of}-\mathrm{Sm}-\mathrm{Te}-\mathrm{Bt}$ & & $1(0.55)$ \\
\hline & Am-Cu-Cl-Ge-Lv-Of-Te-Bt & & $1(0.55)$ \\
\hline & $\mathrm{Am}-\mathrm{Cz}-\mathrm{Cu}-\mathrm{Cl}-\mathrm{Dx}-\mathrm{Sm}-\mathrm{Te}-\mathrm{Bt}$ & & $1(0.55)$ \\
\hline 9 & Am-Cu-Cl-Ge-Lv-Of-Sm-Te-Bt & 1 & $1(0.55)$ \\
\hline Total & & 62 & $121(66.85)$ \\
\hline
\end{tabular}

Am=Ampicillin, Ac=Amoxicillin/clavulanic acid, Ak=Amikacin, $\mathrm{Cz}=$ Ceftazidime, $\mathrm{Cu}=\mathrm{Cefuroxime}, \mathrm{Cl}=\mathrm{Chloramphenicol}$, $\mathrm{Co}=$ Colistin, Dx=Doxycycline, Ge=Gentamycin, Lv=Levofloxacin, Of=Ofloxacin, Sm=Streptomycin, Te=Tetracycline, $\mathrm{Bt}=$ Sulfamethoxazole/trimethoprim 
Delta. The incidence of Salmonella in ants and cockroaches was relatively low in this study, but these insects remain potential carriers of the pathogen at farms and households. Insects also play an important role in the transmission and spread of various avian pathogens, including Salmonella, in the broiler breeder houses $[42,43]$.

The control of pest animals to prevent cross-contamination with Salmonella at farms and households in the Mekong Delta is crucial for the management of infections.

Antibiotic resistance may arise due to the indiscriminate use of antimicrobials and their use as growth promoters and chemotherapeutic agents to control diseases at farms [30]. The Salmonella isolates from the poultry farms were resistant to 2-8 antibiotics and had 17-25 resistance patterns [13,24,25,44]. Most Salmonella isolates in this study showed relative resistance (53.04-62.98\%) to four antibiotics (ampicillin, chloramphenicol, tetracycline, and sulfamethoxazole/trimethoprim), which have been used to treat salmonellosis since many years in Vietnam. The use of antibiotics over long periods thus favors the selection of resistant bacterial strains. Salmonella isolates in this study also showed 62 resistance patterns. This diversity suggests that Salmonella isolates were exposed to various antibiotic agents from multiple sources. Particularly, ampicillin resistance was present in most of the resistance patterns observed in this study, from which we supposed that Salmonella isolates from the poultry and husbandry environments have been exposed to significant amounts of ampicillin. Scur et al. [13] reported that the highest levels of antimicrobial resistance in Salmonella are toward the antimicrobials used over longer periods, which favor the selection of resistant strains. The resistance toward frequently used antimicrobials varies according to geographical locations, production practices, and antimicrobial usage patterns [25]. Salmonella isolated from poultry farms show critically high resistance to ampicillin (100\%), amoxicillin (99\%), and tetracycline (98\%) in Bangladesh [44]. Salmonella isolated from poultry samples also show high resistance to colistin, ciprofloxacin, doxytetracycline, kanamycin, streptomycin, sulfamethoxazole, and tetracycline (42.1$97.6 \%$ ) $[5,6,14-17,25]$. The resistance patterns commonly observed in Salmonella isolates from poultry include amoxicillin-ampicillin-ciprofloxacin-erythromycin-gentamycin-penicillin-sulfamethaxole-tetracycline $(26.4 \%)$ and ampicillin-streptomycin-amoxicillin/clavulanic acid-cephalothin-ceftiofur-cefoxitin $(39.7 \%)$ [24,44]. Resistance to multiple antibiotics makes the treatment of infections caused by pathogenic bacteria, including Salmonella, difficult in both poultry and humans. Thus, the use of antibiotics at poultry farms and households should be controlled to prevent the creation of pathogenic strains resistant to multiple antibiotics, especially Salmonella. Further studies should assess the genetic determinants of resistance and their relationship to Salmonella isolates from poultry and their environment.

\section{Conclusion}

Samples of chickens, farm environments, and pest animals from poultry farms and households were assessed as potential sources of Salmonella in the Mekong Delta, Vietnam. Cross-contamination among these factors may be critical in the spread of Salmonella in these environments. The Salmonella isolates exhibited resistance against various antibiotics and displayed diverse resistance patterns. The antibiotic-resistant strains of the pathogen pose a risk to animal and human health in this area; therefore, biosecurity should be appropriately managed to prevent cross-contamination and subsequent spread of Salmonella. Prospective studies are required to identify the serovars and genetic characteristics of Salmonella isolates to further clarify their pathogenicity for poultry and humans.

\section{Authors' Contributions}

TKN and KTLL: Study conception and design. LTN, TTHC, TTN, and BNT: Acquisition and analysis of data. TKN and LTN: Drafting of the manuscript. TT, HH, and KTLL: Supervised the study. All authors read and approved the final manuscript.

\section{Acknowledgments}

This study was funded in part by the Can Tho University Improvement Project VN14-P6, Vietnam, supported by a Japanese ODA loan.

\section{Competing Interests}

The authors declare that they have no competing interests.

\section{Publisher's Note}

Veterinary World remains neutral with regard to jurisdictional claims in published institutional affiliation.

\section{References}

1. Graziani, C., Losasso, C., Luzzi, I., Ricci, A., Scavia, G. and Pasquali, G. (2017) Salmonella. In: Dodd, C.E.R., Aldsworth, T., Stein, R.A., Cliver, D.O. and Riemann, H.P., editors. Foodborne Diseases. $3^{\text {rd }}$ ed. Academic Press Elsevier, London. p133-169.

2. Silva, C., Calva, E. and Maloy, S. (2014) One health and foodborne diseases: Salmonella transmission between humans, animals, and plants. Microbiol. Spectr., 2(1): 20.

3. Poppe, C. (2000) Salmonella infections in the domestic fowl. In: Wray, C. And Wray, A., editors. Salmonella in Domestic Animals. CAB International, Wallingford. p107-132.

4. Djeffal, S., Mamache, B., Elgroud, R., Hireche, S. and Bouaziz, O. (2018) Prevalence and risk factors for Salmonella spp. Contamination in broiler chicken farms and slaughterhouses in the Northeast of Algeria. Vet. World, 11(8): 1102-1108.

5. Vu, M.D, Nakamoto, Y., Fujiwara, A., Toyofuku, H., Obi, T. and Chuma, T. (2019) Prevalence of Salmonella in broiler chickens in Kagoshima, Japan in 2009 to 2012 and the 
relationship between serovars changing and antimicrobial resistance. BMC Vet. Res., 15(108): 6.

6. Nelson, A., Manandhar, S., Ruzante, J., Gywali, A., Dhakal, B., Dulal, S., Chaulagai, R., and Dixit, S.M. (2020) Antimicrobial drug-resistant non-typhoidal Salmonella enterica in commercial poultry value chain in Chitwan, Nepal. One Health Outlook, 2(18): 4.

7. Pattison, M. and Cook, J.K.A. (1996) Vaccines and vaccination. In: Jordan, F.T.W. and Pattison, M., editors. Poultry Diseases. $4^{\text {th }}$ ed. WB Saunders Company Ltd., London. p469-483.

8. Sanchez, S., Hofacre, C.L., Lee, M.D., Maurer, J.J. and Doyle, M.P. (2002) Animal sources of salmonellosis in humans. J. Am. Vet. Med. Assoc., 221(4): 492-497.

9. EFSA. (2018) European food safety authority and European centre for disease prevention and control (EFSA and ECDC)-the European Union summary report on trends and sources of zoonoses, zoonotic agents, and food-borne outbreaks in 2017. EFSA J., 16(12): e05500.

10. Solghan, M.S., Dumas, N.B., Root, T.P., Quinlan, T.M., Armstrong, L.R., Spina, N.L. and Zansky, S.M. (2010) Multidrug-resistant nontyphoidal Salmonella in New York state's foodborne diseases active surveillance network countries. Foodborne Pathog. Dis., 7(2): 167-173.

11. Wouafo, M., Nzouankeu, A., Kinfack, J.A., Fonkoua, M.C., Ejenguele, G., Njine, T. and Ngandjio, A. (2010) Prevalence and antimicrobial resistance of Salmonella serotypes in chickens from retail markets in Yaoundé (Cameroon). Microb. Drug Resist., 16(2): 171-176.

12. Threlfall, E.J. (2002) Antimicrobial drug resistance in Salmonella: Problems and perspectives in food-and waterborne infections. FEMS Microbiol. Rev., 26(2): 141-148.

13. Scur, M.C., Pinto, F.G.S., Bona, E.A.M., Weber, L.D., Alves, L.F.A. and Moura, A.C. (2014) Occurrence and antimicrobial resistance of Salmonella serotypes isolates recovered from poultry of Western Paraná, Brazil. Afr. J. Agric. Res., 9(9): 823-830.

14. Andoh, L.A., Dalsgaard, A., Obiri-Danso, K., Newman, M.J., Barco, L. and Olsen, J.E. (2016) Prevalence and antimicrobial resistance of Salmonella serovars isolated from poultry in Ghana. Epidemiol. Infect., 144(15): 3288-3299.

15. Zhao, X., Gao, Y., Ye, C., Yang, L., Wang, T. and Chang, W. (2016) Prevalence and characteristics of Salmonella isolated from free-range chickens in Shandong Province, China. Biomed Res. Int., 2016: 8183931.

16. Akinola, S.A., Mwanza, M. and Ateba, C.N. (2019) Occurrence, genetic diversities and antibiotic resistance profiles of Salmonella serovars isolated from chickens. Infect. Drug Resist., 12: 3327-3342.

17. Wang, X., Wang, H., Li, T., Liu, F., Cheng, Y., Guo, X., Wen, G., Luo, Q., Shao, H., Pan, Z. and Zhang, T. (2020) Characterization of Salmonella spp. Isolated from chickens in Central China. BMC Vet. Res., 16(1): 299.

18. Shine, R., Amiel, J., Munn, A.J., Stewart, M., Vyssotski, A.L. and Lesku, J.A. (2015) Is "cooling then freezing" a humane way to kill amphibians and reptiles? Biol. Open, 4(7): 760-763.

19. Lillywhite, H.B., Shine, R., Jacobson, E., Denardo, D.F., Gordon, M.S., Navas, C.A., Wang, T., Seymour, R.S., Storey, K.B., Heatwole, H., Heard, D., Brattstrom, B. and Burghardt, G.M. (2017) Anesthesia and euthanasia of amphibians and reptiles used in scientific research: Should hypothermia and freezing be prohibited? BioScience, 67(1): 53-61.

20. Ungureanu, E.M. (1972) Methods for dissecting dry insects and insects preserved in fixative solutions or by refrigeration. Bull. World Health Organ., 47(2): 239-244.

21. Tran, T.P., Ly, T.L.K., Nguyen, T.T., Akiba, M., Ogasawara, N., Shinoda, D., Okatani, A.T. and Hayashidani, H. (2004) Prevalence of Salmonella spp. in pigs, chickens, and ducks in Mekong Delta, Vietnam. J. Vet. Med. Sci., 66(8): 1011-1014.
22. Clinical and Laboratory Standards Institute. (2019) Enterobacteriaceae. In: Performance Standards for Antimicrobial Susceptibility Testing. $29^{\text {th }}$ ed. Clinical and Laboratory Standards Institute, Wayne, Pennsylvania.

23. Muragkar, H.V., Rahman, H., Ashok, K. and Bhattacharyya, D. (2005) Isolation, phage typing and antibiogram of Salmonella from man and animals in Northeastern India. Indian J. Med. Res., 122(3): 237-242.

24. Alali, W.Q., Thakur, S., Berghaus, R.D., Martin, M.P. and Gebreyes, W.A. (2010) Prevalence and distribution of Salmonella in organic and conventional broiler poultry farms. Foodborne Pathog. Dis., 7(11): 1363-1371.

25. Karabasanavar, N.S., Madhavaprasad, C.B., Gopalakrishna, S.A., Hiremath, J., Patil, G.S. and Barbuddhe, S.B. (2020) Prevalence of Salmonella serotypes $S$. Enteritidis and S. Typhimurium in poultry and poultry products. J. Food Saf., 40(6): e12852.

26. Sharma, S., Fowler, P.D., Pant, D.K., Singh, S. and Wilkins, M.J. (2021) Prevalence of non-typhoidal Salmonella and risk factors on poultry farms in Chitwan, Nepal. Vet. World, 14(2): 426-436.

27. Leotta, G., Suzuki, K., Alvarez, F.L., Nunez, L., Silva, M.G., Castro, L., Faccioli, M.L., Zarate, N., Weiler, N., Alvarez, M. and Copes, J. (2010) Prevalence of Salmonella spp. in backyard chickens in Paraguay. Int. J. Poult. Sci., 9(6): 533-536.

28. Kumar, N., Mohan, K., Georges, K., Dziva, F. and Adesiyun, A.A. (2019) Prevalence, serovars, and antimicrobial resistance of Salmonella in cecal samples of chickens slaughtered in pluck shops in Trinidad. J. Food Prot., 82(9): 1560-1567.

29. Dione, M.M., Ikumapayi, U.N., Saha, D., Mohammed, N.I., Geerts, S., Ieven, M., Adegbola, R.A. and Antonio, M. (2011) Clonal differences between non-typhoidal Salmonella (NTS) recovered from children and animals living in close contact in the Gambia. PLoS Negl. Trop. Dis., 5(5): $1-7$.

30. Ahmed, A.O., Raji, M.A., Mamman, P.H., Kwanashie, C.N., Raufu, I.A., Aremu, A. and Akorede, G.J. (2019) Salmonellosis: Serotypes, prevalence and multi-drug resistant profiles of Salmonella enterica in selected poultry farms, Kwara State, North Central Nigeria. Onderstepoort J. Vet. Res., 86(1): a1667.

31. Wibisono, F.M., Wibisono, F.J., Effendi, M.H., Plumeriastuti, H., Hidayatullah, A.R., Hartadi, E.B. and Sofiana, E.D. (2020) A review of salmonellosis on poultry farms: Public health importance. Sys. Rev. Pharm., 11(9): 481-486.

32. Jibril, A.H., Okeke, I.N., Dalsgaard, A., Kudirkiene, E., Akinlabi, O.C., Bello, M.B. and Olsen, J.E. (2020) Prevalence and risk factors of Salmonella in commercial poultry farms in Nigeria. PLoS One, 15(9): e0238190.

33. Adesiyun, A., Offiah, N., Seepersadsingh, N., Rodrigo, S., Lashley, V., Musai, L. and Georges, K. (2005) Microbial health risk posed by table eggs in Trinidad. Epidemiol. Infect., 133(6): 1049-1056.

34. Shirota, K., Umali, D.V., Suzuki, T. and Katoh, H. (2012) Epizootiologic role of feeds in the epidemiology of Salmonella Senftenberg contamination in commercial layer farms in eastern Japan. Avian Dis., 56(3): 516-520.

35. Raufu, I.A., Ahmed, O.A., Aremu, A., Odetokun, I.A. and Raji, M.A. (2019) Salmonella transmission in poultry farms: The roles of rodents, lizards, and formites. Savannah Vet. J., 2(2019): 1-4.

36. Backhans, A. and Fellström, C. (2012) Rodents on pig and chicken farms-a potential threat to human and animal health. Infect. Ecol. Epidemiol., 2: 17093.

37. Mian, L.S., Maag, H. and Tacal, J.V. (2002) Isolation of Salmonella from muscoid flies at commercial animal establishments in San Bernardino County, California. J. Vector Ecol., 27(1): 82-85.

38. Hamilton, A.M., Paulsen, D.J., Fryxell, R.T.T., Orta, V.E., 
Gorman, S.J., Smith, D.M., Buchanan, J.R., Wszelaki, A.L. and Critzer, F.J. (2021) Prevalence of Salmonella enterica in flies on a diversified cattle and fresh produce farm across two growing seasons. J. Food Prot., 84(6): 1009-1015.

39. Nwachukwu, M.I., Duru, M.K.C., Nwachukwu, I.O. and Anomodu, C.K. (2014) Incidence of pathogenic bacteria in Wall gecko dropping. Intraspecific J. Microbiol. Life Sci., 1(1): $1-6$.

40. Nguyen, K.T., Hasegawa, M., Nguyen, T.T., Vo, T.M.T., Tran, T.H.T., Ly, T.L.K., Taniguchi, T. and Hayashidani, H. (2018) The importance of wild gecko as a source of human Salmonella infection. J. Vet. Med. Sci., 80(8): 1345-1347.

41. Nguyen, K.T., Hasegawa, M., Vo, T.M.T., Huynh, T.L., Nagata, E., Ly, T.L.K., Taniguchi, T. and Hayashidani, H. (2021) Wild geckos considered as the natural reservoir of Salmonella Weltevreden in Southeast Asian countries. Zoonoses Public Health, 68(7): 815-822.

42. Gray, J., Maddox, C., Tobin, P., Gummo, J. and Pitts, C. (1999) Reservoir competence of Carcinops pumilio for Salmonella Enteritidis (Eubacteriales: Enterobacteriaceae). J. Med. Entomol., 36(6): 888-891.

43. Olsen, A. and Hammack, T. (2000) Isolation of Salmonella spp. from the housefly, Musca domestica L., and the dump fly, Hydrotaea aenescens (Wiedemann) (Diptera: Muscidae), at caged-layer houses. J. Food Protect., 63(7): 958-960.

44. Mahmud, M.S., Bari, M.L. and Hossain, M.A. (2011) Prevalence of Salmonella serovars and antimicrobial resistance profiles in poultry of Savar area, Bangladesh. Foodborne Pathog. Dis., 8(10): 1111-1118.

$* * * * * * * *$ 